\title{
The Expression of Emotion and Feeling in Music Composition
}

\author{
Anjun Wang \\ Music and Dance School of Zhongzhou University \\ Zhengzhou, Henan,China 450044 \\ e-mail:34049079@qq.com
}

\begin{abstract}
Emotion is the mental activity brought by peoples' physiology needs. Feeling is the mental activity brought by human social needs. Emotion is the outward expression of feeling, while feeling is the essence of emotion. The two are like the double helix structure of DNA that go together and are inseparable. (2) The music work created by the composer stimulates people's senses first to stimulate the physiological changes. Therefore, to produce an emotional reaction in people, bring emotional experience and achieve the aim of experiencing the affections expressed through the music. (3) Feelings have a social source, therefore, the basis of music works and the creative standing point of the composer must root in the social reality. Only in this way can the music works have a richer expression of affections.
\end{abstract}

Keywords—emotion; feeling; Music composition; expression of emotion

\section{INTRODUCTION}

"Show me what love is". Love, friendship, student-teacher love, and kinship etc,; pleasure, anger, sorrow, fear, love, hate and rest, ${ }^{2}$ etc. all belong to different emotions. What can be used to express different feelings of people? How about the intangible notes composed by the composer? Or the different sounds in nature?

The answer is definitely yes. Music can be used to express people's affections. However, how could music more appropriately express people's affections is a question that music creators must consider. Making a careful analysis and having a deep understanding of people's affections could help the music creators better convey his ideas and feelings. Affection is the combination of emotion and feeling, therefore, we will start with the analysis of emotion and feeling.

\section{Organization of The TeXt}

\section{A. Emotion and feeling}

The two words "emotion" and "feeling" are always used together, called affection. It seems that there is little difference between the two terms, but in fact, they are different. The writer will analyze the terms separately.

\footnotetext{
${ }^{1}$ Quoted from the lyrics of the popular song "Plum Blossom Melody"

${ }^{2}$ Theory of seven affections, quoted from "The Book of Rites"
}

Human needs can be divided into physiological needs and social needs. Emotion is always related to human physiological needs which mainly refer to the needs for the necessities that maintain human existence, such as food, water, air, rest and so on. Whether physiological needs are satisfied or not will directly cause the change in people's emotion. For example, delicious food makes people happy, hungry makes people irritated, and danger makes people afraid, etc.. Emotions mainly have four types: happiness, anger, sorrow and fear.

Feeling is mostly related to human social needs which refer to the needs formed in human social life and produced for preserving the existence and development of society. For example, the need to work and to communicate, the need for friendship, the need for seeking knowledge and for morality. Whether social needs are satisfied or not makes people have different feelings. For example, patriotic feeling, collective feeling etc.. Human social feelings can be divided into moral feeling, rational feeling, and aesthetic feeling.

Emotion and feeling all belong to mental phenomenon. The two words are always used together to refer to mental activities. There is slight difference in the connotation of the two words. Emotion is situational and temporal, while feeling is stable. Emotion usually comes with the current situation or the present needs of people, and also can quickly weaken or fade away with the change of the certain situation or the satisfying of the needs. Whereas feeling is the deep understanding and usual attitude based on the generalization of subjective and objective relationship. It has the quality of stability and profundity.

For example, passionate tune may make our emotions very high, but we cannot maintain the high emotion forever because of the passionate tune we have just heard. For example, listen to the China's national anthem will arouse Chinese people's patriotic feelings; however, even if we don't hear the national anthem, we are still patriotic. Patriotic feelings are stable in people.

Emotion is mostly explicit and impulsive, while feeling is relatively implicit and deep. When people are in a certain kind of emotion, they always have very obvious external behaviors, such as lose one's spirits, dance with joy, and stamp with rage and so on. By contrast, there is no obvious external expression for feeling. Feeling is a deep inner heart behavior which usually exists in the very implicit manner or expresses in the subtle way. When people have certain emotion, it will be very 
hard to control at the moment; while there is no such condition for feeling, since feeling is always in the control of people's consciousness. Even though emotion and feeling have their own characters, the differences are relative. The two are always interwoven together and cannot be separated strictly. In some sense, it can be regarded that emotion is the outward expression of feeling, while feeling is the essence of emotion. In general, the existence of feeling always comes with the emotional reaction, while the change in emotion is mostly controlled by feeling.

\section{B. Emotion and feeling in music}

How does the music reflect and express human's affection? According to the present research in music aesthetics, it is generally recognized that the movements of sound have a kind of isomorphic relationship with people's mental activities.

Ji Kang, the ancient Chinese musician, has certain recognition with music, which is "in order to cause human physiological changes in response to the sound effects, music should first arouse the listener's emotional reaction". In western countries, Hanslick believes that music arouses the listener's physiological excitement by the rising up and fading away in tune. The two musicians considered the influence of music on human as a kind of emotional experience, or a kind of disorder and disturbance ${ }^{3}$. From this point, people's feeling after hearing the music is produced by the emotional fluctuation stimulated by sound to sense organ.

In $19^{\text {th }}$ century, Russian composer Tchaikovsky composed his famous symphony "Pathetique". From the music dynamic structure of the principal theme part in the fourth chapter of this symphony we can see that, the sigh and going down melody, and the unstable harmony and the overlapped string section have certain isomorphic relationship with people's mental feelings.

Form China neoteric musician Hua Yanjun's Erhu solo "The Moon over a Fountain", we can feel that the plaintive melody is just like a man telling a sorrowful story to you. The famous Japanese conductor Seiji Ozawa said in tears after hearing the Erhu solo "The Moon over a Fountain", "It is disrespectful if we stand to hear this music, we should kneel to hear." From his words, we can see that the good music works really can touch people's hearts directly.

In everyone's heart, there is rich psychological experience, as mentioned by Ji Kang in his "Voice without Grief and Joy Theory", "first encounter in heart". After hearing a piece of music, the stimulation of sound has aroused people's inner heart experience, as mentioned by Ji Kang in his "Voice Without Grief and Joy Theory" the sound causes people's feelings. Therefore, emotional and rational, conscious and subconscious have interwoven and mixed together, forming people's inner feelings.

\section{The expression of emotion and feeling in composition}

The music we have just talked about could reflect and express people's affections. Therefore, how to organize and

\footnotetext{
${ }^{3}$ Xiu Hailin, Luo Xiaoping, The General Theory of Music Aesthetics, Shanghai Music Publishing House, 2002, P326.
}

employ music to express human emotion and feeling in composition? Or how to express certain affection the composer want to express in composition? The following is some points and opinions of the writer.

First, we have recognized that emotion is the psychological changes brought by physiological stimulation, and the change in emotion is the precondition of feeling experience. Therefore, the music work we created should first stimulate physiological changes through the stimulation of human sensory organs to bring human feeling reaction, and thus cause the feeling experience. At last, it will achieve the goal of experience the affections expressed in the music. As shown in the following chart:

Affections of the composer $\longrightarrow$ notation symbol $\longrightarrow$ sound effect $\longrightarrow$ stimulation of the sensory organs $\longrightarrow$ physiological change $\longrightarrow$ emotional change $\longrightarrow$ social reality $\longrightarrow$ subjective experience $\longrightarrow$ feeling experience $\longrightarrow$ affections of the listener

For example, in the Song Dynasty musician Jiang Kui's "Apricot Blossom" in China, the lyrics " the tides know better of my bitter for lovesickness" employs the nearly half step to make descending tone. This makes the listener feel the sorrow expressed by the creator. The modern composer Jin Xiang employed dissonance in the prelude of his symphonic chorus "Sacrifice in Jingling". The harsh sound stimulation almost makes people lose their breath and deeply feel the bloodsoaked Nanjing massacre in 1937 described in the music.

\section{1) Emotional expression}

From the analysis of the relationship between emotion and feeling, we can get a lot of enlightenment. If a composer records the sound effect by the notes, it is called composition in general. This concept has emerged from the modern and postmodern style composition techniques. In order to express the feeling we would like to express, there are numerous sound effects that we can use freely to stimulate the listener's sensory organs to produce emotional changes. If we are going to describe the pleasant bring to people by the spring brook, harp arpeggio can be used to express with the warm violin string orchestra as the background. We can also use the fade away and fade in drum roll of cymbals to express in the clear and melodious bird twitter produced by the flute. We can use waltz parts of the cheerful piano, adding the gentle harmony background part and the clear arpeggio in the upper register of piano to express this emotion. Still, we can use the real sound in nature completely to express this kind of emotion by the sounds from the concert performer personally fiddles water in the basin under the background of soft string. What is emotion for? In the eyes of the composer, emotion is the various sound effects that could stimulate the listener's sensory organs to cause changes in emotion and feeling.

Under different social condition, different composer have different emotional impressions, and thus they could write different music works. When the composer Handel created his music work "Messiah", he never walked out of his room and hardly had a rest. Romain Rolland said, "He created the work by his tears". When Handel finished the chorus "Hallelujah" in the work, he was moved to tears by his composition, and 
yelling, "I have seen the heaven and Jesus". Jorge the Second presented in the first performance. When he heard the chorus "Hallelujah", he couldn't help to stand. Since then, it has been a rare tradition to stand to hear "Hallelujah" in music history.

China modern composer Tan Dun tried to include all sound effects that could stimulate the listener's sensory organs in to music like water music, pottery music and paper music, etc., and thus created a number of famous pioneering music works. The composer who put his heart and soul into composing tends to pay attention to how to express his inner emotion through the dynamic movement of music. However, there is some playing music behavior that doesn't contain any emotion, just like number games. This kind of creation doesn't represent the mainstream of music creation. It is only admitted in a very small circle at most and will be eliminated from art at last. ${ }^{4}$

\section{2) Feeling expression}

Feelings have a social source, therefore, the basis of music works and the creative standing point of the composer must root in the social reality. Only in this way that the music works have a richer expression of affections.

For example, China composer Xian Xinghai's "the Yellow River Chorus" put its standing point to the Yellow River, the mother river of the Chinese nation, and made this work as the horn to inspire Chinese people to strive to be strong. Therefore, this work has a wide affection meaning, which has moved many people to tears and aroused thousands of Chinese people patriotic feelings.

Violin concerto "the Butterfly Lovers" of the composer He Zhanhao and Chen Gang has described the theme of love that never changes. It is because of this theme that the touching sound effects are more likely to cause people's feeling experience and feeling resonance. It is also because of this theme that makes "the Butterfly Lovers" more widely spread and becomes the classical work among Chinese music works.

One major reason for Beethoven became one of the greatest classical composers is that his works have wide social meanings. The sanding point of the Sixth Symphony "Countryside" of Beethoven is nature; the sanding point of the Fifth Symphony "Fate" points to human himself; the sanding point of the Ninth Symphony "Ode to Joy" points to the society, calling for the millions of people work together as brothers. Nature, human and society, how great his standing points are! What expressions of deep feelings! This is the major reason that his works become the treasure of the whole human world.

\section{CONCLUSION}

To sum up, affection is the soul of human spiritual world and the center of composer's music expression. Affection is the important opponent that composes the complicated live being--Human. All kinds of human social activities and culture inheritance are caused by human affection. Form the poetry "Guan Ju" to the violin concerto "the Butterfly Lovers", we don't know how many works have praise love. Form the poetry in China Tang Dynasty "At the top of the mountain where brother gather together, there is one miss" to the modern China song "It is the time of missing hometown in the deep and quiet night", we don't know how many works have describe the affection between family members. Affection is the soul of human spiritual world and it is very important for people. However, affection is mysterious and intangible. We live in affections but we barely know about it. We analyze affection in order to better understand and demonstrate it. Emotion and feeling is the organic opponent of affection, just like the double helix structure of DNA that go together and are inseparable. Affection need to be placed properly and hope to be expressed. In the ancient and modern word, does there any artist work that contain deep affection? Fortunately, music can be used to express affection. The composer could experience the emotion and feeling of human society meticulously, use various notes to express human emotion and feeling in human heart, and to express the most real affection.

\section{REFERENCES}

[1] Xiu Hailin, Luo Xiaoping. The General Theory of Music Aesthetics [M]. Shanghai Music Publishing House, 2002.

[2] Ki Changhe. The Dichotomy of Psychological Activities [J]. Journal of Xi' an Normal College, 1981(4).

[3] Luo Xiaoping. Music and Literature [M]. People' s Music Publishing House, 1995.

[4] Cao Richang. General Psychology (the second volume) [M]. People's Education Press, 1980.

[5] Zhou Wenjian. The Unification of Emotion and Feeling in Chorus [J]. Art Exploration, 2006(S2).

[6] Zhao Hua. Research on the Function of Knowledge and Feeling in Composition [J]. All Circles, 2007(6)

\footnotetext{
${ }^{4}$ Xiu Hailin, Luo Xiaoping, The General Theory of Music Aesthetics,

Shanghai Music Publishing House, 2002, P343.
} 